\title{
My school is my nation project: paths for the construction of school identity
}

\section{Projeto minha escola é minha nação: caminhos para construção da identidade escolar}

\section{Proyecto mi escuela es mi nación: formas de construir una identidad escolar}

\author{
Renata Pereira de Lacerda1 ${ }^{\text {iD }}$, Rosebelly Nunes Marques ${ }^{2}$ iD \\ 1 PECEGE Institute, Piracicaba, São Paulo, Brazil. \\ 2 University of São Paulo, São Paulo, Brazil. \\ Corresponding author: \\ Renata Pereira de Lacerda \\ Email: rena.lacerda@gmail.com
}

\begin{abstract}
How to cite: Lacerda, R. P., \& Marques, R. N. (2021). My school is my nation project: paths for the construction of school identity. Revista Tempos e Espaços em Educação, 14(33), e16475.
\end{abstract}

http://dx.doi.org/10.20952/revtee.v14i33.16475

\begin{abstract}
This study presents and discusses the actions for the implementation of a project. The project was started in a school unit in the State Education Network in the state of Sao Paulo in the Integral Education [PEI], located in the city of Piracicaba - SP, as a way to guarantee the expansion of democratic management within the school, The objective of this work was to present and discuss the relationship between the constitution of the project in a comprehensive way, with the results of the actions that have already been carried out at the school. The school's documents were analyzed, as well as the legal documents and the relevant bibliography. These all have a purpose to theoretically support the project, giving it a well-founded basis for its implementation. The purpose is to expand the democratic rights within the unit to allow Class Assemblies, corroborating with the democratic management, which will provide the school with a path towards its own identity. Along with the studied literature, the school's internal documents and the results of the actions already carried out at the school, all validate the project's viability. There is legal support for its implementation by meeting these proposals. Positive results corroborated the continuity of the successful practices by the analysis of data and the actions already carried out at the school which gives the full implementation of the project.
\end{abstract}

Keywords: Class assembly. Democratic management. Feeling of belonging. Integral education program. Youth protagonism. 


\section{RESUMO}

Este estudo apresenta e discute as ações para a implantação de um projeto, dentro de uma unidade escolar da Rede Estadual de Educação do Estado de São Paulo, inserida no Programa Ensino Integral [PEI], localizada na cidade de Piracicaba - SP, como forma de garantir a ampliação da gestão democrática dentro da escola. O objetivo deste trabalho foi apresentar e discutir a relação da constituição do projeto de forma integral, com os resultados das ações que já foram realizadas na escola. Foram analisados os documentos da escola, bem como os documentos legais e bibliografia pertinente, com o propósito de embasar teoricamente o projeto, e dar-lhe bases fundamentadas para sua implantação, que tem como propósito ampliar os espaços democráticos dentro da unidade através da implantação de Assembleias de Classe, corroborando com sua gestão democrática e, ainda, no intuito de propiciar à escola, um caminho para uma identidade própria. Tanto a literatura estudada, quanto os documentos internos da escola, além dos resultados das ações já realizadas na escola, validaram a viabilidade do projeto, e foram ao encontro de suas propostas, assim como também este, encontrou apoio legal para sua efetivação. A partir das análises dos dados das ações já realizadas na escola, foi possível encontrar resultados positivos que corroboram com a continuidade de suas práticas bem-sucedidas, tendo em vista a implantação integral do projeto.

Palavras-chave: Assembleia de classe. Gestão democrática. Programa ensino integral. Protagonismo juvenil. Sentimento de pertencimento.

\section{RESUMEN}

Este estudio presenta y discute las acciones para la implementación de un proyecto, dentro de una unidad escolar de la Red Estatal de Educación del Estado de São Paulo, inserta en el Programa Ensino Integral [PEI], ubicada en la ciudad de Piracicaba - SP, como forma de asegurar la expansión de la gestión democrática dentro de la escuela. El objetivo de este trabajo fue presentar y discutir la relación de la constitución del proyecto de forma integral, con los resultados de las acciones que ya se han realizado en la escuela. Se analizaron los documentos de la escuela, así como los documentos legales y la bibliografía pertinente, con el fin de fundamentar teóricamente el proyecto, y darle una base bien fundamentada para su implementación, que tiene como objetivo ampliar los espacios democráticos dentro de la unidad a través de la implementación de Asambleas de Clase, corroborando con su gestión democrática y, también, con el fin de proporcionar a la escuela, un camino hacia su propia identidad. Tanto la literatura estudiada, como los documentos internos de la escuela, y los resultados de las acciones ya realizadas en la escuela, validaron la viabilidad del proyecto, y cumplieron con sus propuestas, así como esto, encontraron apoyo legal para su implementación. A partir del análisis de los datos de las acciones ya realizadas en la escuela, fue posible encontrar resultados positivos que corroboran la continuidad de sus prácticas exitosas, de cara a la plena implementación del proyecto.

Palabras clave: Asamblea de la clase. Gestión democrática. Programa de educación integral. Protagonismo juvenil. Sentido de pertenencia.

\section{INTRODUCTION}

The viability of a Democratic Management is a great challenge for the school manager: it is necessary, increasingly, to be able to open ways to leave the role of centralizer of power, and start to have a more collective attitude, rethinking its practice, taking then from this, decisions that have been decided in a shared way. For this to happen effectively, it is necessary that the manager manages to provide these spaces for participation and exercise of citizenship, democratizing social relations and developed practices (Oliveira, 2009), as suggested by Falcão and Silva (2020, p.6), 
The construction of democratic management in public schools requires an organization of work that is conducive to collective action and the existence of institutional instruments and mechanisms to ensure the participation of different segments of the school and local community in management processes and in decision-making on different issues of interest to the school.

The role of the school has been redefined over time, making it necessary for it to become more democratic, inclusive, and participatory, opening opportunities for new actions to be inserted in its scope, which carry forward the democratic processes and the full training of students, future citizens, so that they are able to effectively exercise their citizenship, transforming their reality and acting in a critical, ethical, fair, and democratic way. The Federal Constitution of 1988 in Article 205, and the Law of Directives and Bases (LDB) (Brazil, 1996) in Article 2, provide for this preparation for the exercise of citizenship as a duty of the State and a Social Right, which the school must fulfill.

As Lück (2010) rightly notes, it is no longer enough for the school to serve only to teach the student to prepare for a higher level of schooling, so that it meets only their internal requirements, but rather, to promote their development in terms of meaningful skills, taking as a central point the evolutionary needs to face each stage of his life: he must learn to understand life and society, how he is inserted in this context and how he can influence it and be influenced by it. In the same direction, Amorim, Matta and Freitas (2017, p. 1804), considers it important:

School management should be closely interconnected with the dynamism of innovations in education, in other areas of knowledge, in society, in the school system and in the school unit itself. These aspects are currently understood to be a historical necessity, to meet the demands for access, permanence, and educational success, involving, therefore, the emancipation and construction of citizenship for all the millions of students who attend basic education throughout the country.

The more students learn at school, through experiences of situations, the better and easier it is expected to be to face the challenges that contemporary society imposes autonomy to act individually and collectively, in a flexible way, knowing how to make assertive decisions with ethical principles that, besides being democratic and inclusive, are also supportive and sustainable, as also foresees, the Common National Curricular Base [BNCC] in its General Competencies (Brazil, 2017).

It is expected that once they have participated in some action, they will have learned to participate in it (Bordenave, 1994). And democracy being the pillar of Democratic Management, from the moment students actively participate, and change the way they relate to each other, they gain the possibility to negotiate their points of view and develop skills and competencies to solve their problems.

One of the school models that meets these ideas is the PEI, of the State of São Paulo, which has in its Guidelines (São Paulo, 2012) a pedagogical model and a management model that provides students with contact with diversified subjects in their curriculum, which assist in the development of their social and emotional skills, to stimulate their potential and provide moments when they can act as protagonists in the construction of their own learning, and also contributing to the idealization of a school and a quality education. However, there is a gap between what is established and what is up to the school to accomplish, and it is up to the school manager to find ways to make possible what the document proposes.

Both Comprehensive Education and Democratic Management are part of the National Education Plan [PNE] specified in its goals 6 and 19, respectively (Brazil, 2014). As stated in this document, Brazil should, in 10 years, achieve its 20 proposed goals, having the force of law. According to the 2018 report, considering the goals pertinent to this study, in relation to Comprehensive Education, $13.5 \%$ of the goal has been reached, out of a total of $25 \%$, and as for Democratic Management, there is no data that shows how much we have advanced in this period, 
according to the National Institute of Educational Studies and Research [INEP]. Considering that, two of the needs for the existence of the PNE, are to reduce social inequalities and democratize management, it is important to note what they observe (Schimonek \& Adrião, 2018, p.241), when they say that

Full-time education can help reduce educational inequalities, if it is designed and structured with sufficient resources to change the conditions of education supply as it is. This means considering that the reduction of educational inequalities, even if it does not result exclusively from the performance of and in schools, has in the improvement of these performances a fundamental factor for its confrontation. This, in turn, will only be effective when considered as an element for the realization of the right to education and, therefore, as a commitment of the State to the new and more vulnerable generations.

In an attempt to help fill the gap that exists between what is stated in the documents and the effective school practice, the idea arose to develop and implement in the school, the My School is My Nation Project which, in a contextualized and playful way, through methods for conflict resolution, seeks to exercise empathy, protagonism and democratic actions, As Bourdieu (2007) says, school is one of the possibilities of a place where one can acquire these potential resources (social, cultural, material, intellectual), which, when socially mobilized, generate benefits for those who acquire them. As Yamazato and Nascente (2020, p.13) in relation to the theoretical bases of the curriculum project of the CIEPs, we can also observe, in this sense, that the bases of this project are similar: "The theoretical bases of this project, according to Silva (2009), were based on the pedagogy of John Dewey's New School, on Bourdieu and Passeron's theory of symbolic violence, and on Paulo Freire's theory "[...] in which "the process of learning to read and write is always linked to the exercise of critical reading of the world" (p. 19).

There are already examples of schools that have introduced projects to strengthen the sense of belonging in students in relation to them and have reaped fruit: Project Ser e Pertencer of E.M. Bernardo de Vasconcellos school (RJ), whose democratic management led students to the exercise of protagonism, rescuing self-esteem, identity and pride of belonging to the community, as well as the revitalization of the school space (Fernandes, 2017); Project Me, My School and My Neighborhood, of E. M. Casa da Criança Maria Antônia (MG), which proposed to rescue the identity of the school through actions integrated with the community and to value local culture through artistic expressions (Lisboa, Jamar, Santos, \& Lopes, 2014); and the E.M.E.F. João R. P. Abolicionista (SP) that, thinking of preparing its students for democratic experience, holds class assemblies to discuss the school's problems (Valle, 2016).

This appreciation adheres to the paradigm of student-centered pedagogy as part of projectbased learning, "because by working on a project, each student can find a job that best suits his or her interests and abilities" (Zhannat, Kuatovna, Asauovna, Rahmetzhanovna, Zina, Darazha, Saira, \& Salamatovna, 2021, p.833).

Thus, based on this perspective of valuing the student and seeking solutions to school demands, the purpose of this paper is to present and discuss the results of the actions that have already been taken at school and their relationship to the constitution of the project in a comprehensive way. Such actions have provided a guide for the composition of the project and, by being successful, have favored its forwarding to the organization and the formation of its identity. The Class Assemblies were the trigger that triggered this whole process.

\section{METHODOLOGY}

The method used for this work was qualitative and documentary research in education. Pertinent legal documents were analyzed - Federal Constitution (Brazil, 1988), LDB (Brazil, 1996), 
PNE (Brazil, 2014), BNCC (Brazil, 2017), the National Curricular Parameters [PCNs] (Brazil, 1997), and the Guidelines of the Comprehensive Education Program (São Paulo, 2012) - as well as a theoretical study of the school's documents, namely, its School Regulations, the Management Plan, where its Pedagogical Political Project [PPP] is inserted, and the Action Plan, elaborated from the annual demands of educational outcomes.

The choice of this approach is interesting because it can raise questions and make discussions during the investigative course, creating and recreating possibilities to understand the complexity of relationships among the various objects of study and analysis, so that such possibilities are hypotheses free of any evidential role, and serve as a reference to confront the reality of the study (Suassuna, 2008).

The object of study of this work carries a series of complex relationships and multiple dimensions in its application and, therefore, again as Suassuna (2008) suggests, this approach enables ways to explain reality by situating its findings in a broader context, building, and structuring a theoretical panorama that allows a better interpretation and understanding of the case studied.

The proposed work, while taking place within the school environment, full of countless challenges, full of diversities and pluralities that form and shape its internal environment, intensifies the need for a very well contextualized analysis. And for there to be this contextualization and correct analysis of their questions, it is necessary a direct and continuous contact with their daily lives, and a constant analysis of this enormous complexity, corresponding with what Bogdan and Biklen (1982) indicate, who argue that this research concept presents some basic characteristics: it has as its data source the natural environment, where its main instrument is the researcher; it justifies everyday contact, where the particular circumstances in which the object of study is inserted, are essential for its understanding, and where each data of the reality is considered important; the data collected are mainly descriptive; the researcher must be attentive to every detail, because each element can be considered essential to better understand the problem; and it considers the diverse points of view of the participants, allowing a clear view of the internal dynamics of the situations. In other words, a methodology that makes it possible to obtain descriptive data in loco, valuing the process more than the result produced, and concerned with the faithful portrayal of the perspective of all those involved.

The school involved in this study is in Piracicaba, in the interior of São Paulo, and has students who, because they are part of the IEP, already have several spaces for democratic participation and protagonism, such as the Student Union, Youth Clubs, Tutoring, Class Council, as well as the free choice of elective subjects in which they wish to participate. Not only on paper, but in fact, the students actively participate in these spaces: democratic processes are held for the election of class representatives and the election of the Student Council. For the clubs, it works the same way: students suggest options for the clubs, go around the classrooms to publicize them and, together with the management, decide which ones will take place, and the authors of the proposals will be the leaders of these clubs, run by themselves. This school format also puts the student in contact with diversified disciplines, among them, Life Project (PV) and Youth Protagonism (YP), during which, starting in 2019, the school started to hold Class Assemblies to stimulate and illustrate citizenship actions, seeking to show in the practice of its processes, the concept of citizenship as the practice of rights and duties, and how they are interconnected, in a two-way street. The Class Assemblies, following the example of the class leaders' actions, can favor "the acquisition of responsibilities in a work that involves the common good, which generates significant learning for life in society and a sense of belonging of these students to the school" (Falcão \& Silva, 2020, p.14). The diversified discipline of PCV is the flagship of the IEP: it is the component that guides and directs the attitudes and actions within the school (students and teachers, management, and other school unit employees) being worked in a joint and transdisciplinary way. As soon as they arrive at a PEI school, the new students are welcomed by students who are already studying at the school, called 
Welcoming Students, whose first function is to welcome these new students, introducing them to the premises and pillars of the program, and through dynamics, they begin the process of selfknowledge and the process of thinking of dreams, which will be the starting point for their life projects. The VP has important guiding principles, such as the development of socioemotional skills, the pedagogy of presence, and student protagonism. The elective courses that will be offered in each semester are based on these first dreams pointed out by the students, whether they are newcomers or students already studying at the school. In the case of the Elementary II school in question, the PV themes are, for each year: "Me and the other" (6th grade), "Me and my projects" (7th grade), "Me, us and the world" (8th grade) and "Me and my purpose (9th grade). The diversified subject of MY complements that of PV, providing the students with subsidies for the understanding of protagonism in practice, the initial visualization of being the writer of one's own history, being an educational principle of the integral education program, essential for a real teaching and learning process. The MYP is organized in Learning Situations, distributed throughout the years, also following thematic themes: "The school where we want to study" (6th grade), "The school community" (7th grade), "My school and my family" (8th grade), and "My school and the community" (9th grade).

Within the whole context that permeates the Comprehensive Education Program, after these assemblies were held, the idea arose to develop and implement the My School is My Nation Project, to enable, in the form of practical actions for the exercise of democracy, an increase in student participation in decisions that concern them, and school as a whole, in order to help them acquire cultural and social capital and to contribute to the increase of their feeling of belonging in relation to the school, collaborating with the development of their autonomy, empathy, belonging, and ability to make decisions:

Autonomy for the student to self-perceive himself as a citizen builder of the ethical world, and therefore respected, being able to value his image and inner experience, being able to grow individually and collectively, projecting quality results in his learning, in his personal and collective life (Amorim, Matta, \& Freitas, 2017, p. 1816).

Therefore, to prepare this project, it was necessary, at first, to conduct a study and an analysis of the documents that permeate the school and its educational processes, in order to theoretically ground its actions, valuing its regional characteristics, considering its reality, and based on the PEI Guidelines (São Paulo, 2012): this was the beginning of the creation of a project that seeks to assist in solving the demands of the democratic management of the school, as well as its problems, in a contextualized manner, grounded and prepared within this documentary survey. This step was carried out with the school management, to start the construction of the project, and to solve its funding, through the financial resources available. It is important to highlight that this project, the way it was thought, needs low cost to be feasible: stationery materials, which the school already provides, sports vests used in Physical Education classes, and a banner-shaped panel with plastic pockets, to monitor the evolution of the classrooms' indexes, whose cost today is around $\mathrm{R} \$ 200.00$. As it fits into pedagogical material, this cost can be paid with funds collected by the Parent-Teacher Association [APM] or with the money from the Programa Dinheiro Direto na Escola Paulista [PDDE], via direct payment by bank transfer, through a legal account.

In a second moment, within the democratic movement inherent to the processes of implementation of democratic management within the school, and the elaboration and implementation of the project, there was a presentation of the project planning during the General Collective Pedagogical Work Class [ATPC] time (management and teachers): to clarify its proposal and its means of functioning daily, seek other perceptions, solve possible doubts, and listen to suggestions and criticism. 
The third moment involved getting to know and recognizing the profile of the students, as well as thinking about how the practices and moments of protagonism, the exercise of democracy, and the experience of citizenship would be carried out within the project, within the school, establishing the Class Assemblies as the initial moment of the experience of the democratic process, triggering the other actions of the project.

The idea of 'Nation' is important for the project, because it appears here inspired by the vision of Pena [200-?], who understands that the feeling of belonging should be awakened in the group, so that there is the will of individuals to together form this nation. The school has been moving in this direction, especially after the implementation of the IEP in 2016, and a large part of the students are already immersed in this feeling of belonging, generating visible results of improvement in school relations. However, to effectively achieve the project's goal, it is necessary to involve the students even more, through the experiences of the Class Assemblies, a moment of citizenship exercise within the school, and the strengthening of its democratic processes.

\section{RESULTS AND DISCUSSION}

\section{School unit characterization}

The school involved in this work serves the Elementary School - Final Years and has a history of commitment to the teaching and learning of its average of 350 students. In 2016, it joined the Integral Education Program of the State of São Paulo, entering a new model of management and education: training young people for life, autonomous, competent, and solidary citizens, as provided in the Guidelines of the Integral Education Program (São Paulo, 2012).

Its management team consists of the principal, vice-principal, and general coordinating teacher [PCG], supported by area coordinating teachers [PCAs], who each monitor the work of the teachers in their areas, which are: Languages and Codes, Natural Sciences, Mathematics and Human Sciences. The vice-principal oversees monitoring the progress of the subject Life Project and the progress of the Tutoring. The PCG monitors the Elective subjects and the Youth Protagonism, as well as follows the interdisciplinary process between the diversified subjects, the São Paulo Curriculum (São Paulo, 2020) and the BNCC (Brazil, 2017). Vertical and horizontal alignment meetings are held, among everyone, according to the school unit's organizational chart, on a weekly basis.

Its teachers work under the Full and Integral Dedication Regime [RDPI], with a workload of 40 hours per week in the school unit. They have study hours and time to dedicate to their continuing education. All lesson planning should also be done at school. There are no substitute teachers to replace the classes of teachers who need to be absent, so it is up to the others to replace the absent colleagues, which is why the hours for study and lesson planning sometimes turn out to be insufficient. Each teacher receives a group of 20 to 22 students to tutor, a choice made democratically by the students themselves. The tutoring hours are once a week, during the students' lunch break.

The permanence of the professionals who integrate the school team in the Program is conditioned, among other things, to the evaluation of their performance through observation of the professional performance in the development of competencies that are foreseen for the RDPI, according to Resolution SE-68, of 17 Dec. 2014 (São Paulo, 2014). These competencies, which have their origins in the PEI premises, are included in its Competency Map (São Paulo, 2015), which are Continuing Education, Excellence in Management, Protagonism, Co-responsibility, and Replicability. Each professional must prepare their Action Program based on these competencies, annually, detailing the actions that will be developed, and to align their performance with the PEI Guidelines (São Paulo, 2012). Both teachers and managers undergo a performance evaluation, the 360 Evaluation, at which time it is identified whether the teacher (or manager) is developing and applying the competencies and the PEI premises in the performance of his or her duties, with 
reference to the Competency Map - Programa Ensino Integral, mentioned above. This process has the following steps: evaluation of the competencies, evaluation of the professional's performance in the program, calibration of the evaluation of the competencies, consolidation of the final evaluation, and feedback of the final evaluation. The evaluation of the competencies must be done by means of questionnaires filled out individually and confidentially by all the students and by all the professionals of the Teaching Staff working in the school unit. The evaluation of the professional performance of teachers is done by those directly responsible for them (PCAs and PCG) and is done through objective information, considering their attendance and compliance with planned actions (Action Program). The calibration of the evaluation of teachers' competencies should be carried out by the PCAs, the PCG, the Vice-principal and the school Principal. The 360 o evaluation, along with the attendance of each professional, provide subsidies for the permanence, or not, of the professional within the IEP, also considering their self-assessment. This entire process should be monitored by the school unit's Teaching Supervisor and the Coordinating Teachers of the Pedagogical Centers. (São Paulo, 2014). As a way of valuing the educators in this school format, there is a $75 \%$ bonus on the base salary.

Its students have contact with diversified subjects in the curriculum that help them develop cognitive and socio-cultural aspects, in addition to socio-emotional skills, stimulating their potential, and favoring moments when they can act in a protagonist way in the construction of their own learning: Study Guidance, Experimental Practices, Youth Club, Elective Subjects (developed taking into account the students' interest in their life projects), in addition to the aforementioned Youth Protagonism and Life Project.

In 2017 there was a change of direction, and the school received a principal with a history of more effective democratic actions, who brought with her a different vision of conducting school management, more consistent with the model of comprehensive education that the school is. With a more humanized vision, she renovated the school environment in several ways, using the available materials and resources, providing students with a more colorful and cheerful environment, with plants and flowers. It inserted the school in several projects, among them the MuroArte (2019), which uses the Artexperiência (2019) methodology, an educational and artistic action that helps create affective bonds among the participants, through the production of a collaborative action that created an artwork on the school's wall, composed by the handprints of 600 people, among them, the 350 students, managers, teachers, employees, parents, and people from the community. It was a project idealized by an agency and a local artist, with the support of the Regional Board of Education, and is part of the school's actions to increase the sense of belonging of the students, employees, and the surrounding community. Now the school also participates in two ongoing projects: Covid-19 Prevention, due to the current motivator - the pandemic and the consequent quarantine with the suspension of school activities, and the Conviva Project. The Conviva Project is also part of the actions to improve the school climate; it focuses on safety, harmonious coexistence among everyone to curb violent actions among students, among them Cyberbullying. If we analyze what Frick, Menin, Tognetta and Del Barrio (2019) identified in the literature, regarding anti-bullying strategies, the Conviva Project, beyond this moment of pandemic, as well as the project that this work is about, agree on the fact that they consider important forms of bullying prevention, actions "related to improving coexistence, via the development of peer support systems (COWIE; WALLACE, 2000), which place students as the protagonists of the actions. In these systems, students are trained to provide help and learn, for example, basic skills -such as active listening, empathy, assertiveness, communication, solidarity, assertive problem solving, and ways of giving support- as well as expression of feelings and emotions (Frick et al., 2020, p.1169). Socioemotional skills and the expression of feelings and emotions are also worked in the disciplines of the diversified part of the IEP, as in Life Project and Youth Protagonism, besides being issues constantly addressed in the other 
disciplines of the BNCC. Such actions are also linked to the attempt to reduce bullying cases, since it fosters empathy and teaches to control impulses. (Frick et al., 2019).

The school also has some teachers who already use active methodologies in their classes, such as the Inverted Classroom, used in Physical Education, which was very well accepted by the students. The school has the following official documents: the School Rules and Regulations, which, among other things, deal with Democratic School Management; the School Action Plan, published annually; and the School Management Plan, a four-year plan, in which is found its Political Pedagogical Project.

The School Regulation deals, in its Titles: I, with the Objectives of School Education; II, with the Principles of Democratic Management; and III, with its Technical and Administrative Organization.

The Action Plan is prepared based on data from the Results Improvement Method [MMR], part of the State of São Paulo's Management in Focus Program, and presents the school's Mission, Goal and Values, as well as its timetable and results in external evaluations. The MMR points out and focuses on the root cause of the school's problems, proposing actions to be developed to solve them. It brings as values the promotion of juvenile protagonism, continuous training, coresponsibility, excellence in management, and replicability, competencies that also compose the PEI premises. It presents the report card of the school results in the São Paulo State System of School Performance Assessment [Saresp], which shows a significant increase in the performance indicator from 2015 to 2017, a slight decrease in 2018, and a sharp drop in 2019, which has been demanding efforts to correct the learning failures of the skills that were lagging, as proposed in the MMR of 2020.

The School Management Plan includes, in Chapters I and II, the identification and characterization of the school, as well as its clientele and human resources. In Chapter III, it deals with its Political Pedagogical Project, with its values, principles and premises, social function, mission, vision of the future and objectives of the school, as well as its Plan of Action and Pedagogical Proposal. In its Chapters IV and V, the Course Plans and Work Plans of the different school nuclei. Chapter VI deals with the Criteria for monitoring, control, and evaluation of the execution of the work done by the different actors of the educational process.

The Political Pedagogical Project and its Pedagogical Proposal encompass everything that makes the schoolwork in its annual planning: protagonism, activities of the student council, actions of the welcome students and room leaders, youth clubs, tutoring and leveling actions, as well as all the school projects, spaces and actions that work very well in this school. In this sense, the school goes against the trend noted by Falcão and Silva (2020), who observe that the student does not participate in the important decisions of the school, not being called to give his opinion, or even interfere in issues directly related to him, situations considered discouraging to participation and protagonism.

These three documents strengthen and complement each other and point in the same direction: to implement democratic management at school, to provide for the full development of the student and his preparation for the exercise of citizenship, to form citizens aware of their rights and duties, to enable a greater degree of autonomy in all areas, aiming at intellectual development and critical thinking. However, at no time do the school documents contemplate the guarantee of class assemblies.

For the implementation of the project, the change in the direction of the school unit was fundamental, because there was openness for the presentation of the proposal and total support for its elaboration and implementation. 


\section{My school is my nation project}

There is no way to promote an effective democratic school management, without the participation spaces are effective and guaranteed in school, and without moving through the concepts of autonomy, dialogue, sense of belonging, dignity, democracy, citizenship, and politics. This thought is in line with what Amorim, Matta, and Freitas (2017) think, when they say that the understanding about the contemporary school "should contemplate principles and values that strengthen the formation and citizenship of the student, directing this formative process to reveal the importance of living in society, in an ethical, democratic, and participatory way.

Senge (2005), in Schools that learn, brings the importance of a transformative pedagogy that seeks the active involvement of the learner, and that extends from the classroom to the world. A pedagogy that provides ways of thinking about the world in a critical way, which results in a process of self-transformation and social transformation. Senge (2005) also says that schools can and should be recreated, becoming a meeting point for learning, where everyone can improve and expand their consciousness and capabilities through a collective vision. The CIEPs (Centros Integrados de Educação Pública), created in the 1980s and inspired by Anísio Teixeira's experience, are also schools that sought "to be more than just schools, they were centers of education that provided opportunities to put on an equal footing the social and cultural condition of the various and unequal social classes, constituting themselves as 'miniature communities' (Yamazato \& Nascente, 2020).

The project Minha Escola é Minha Nação was born with the goal of expanding the spaces for student participation, bringing the proposal to hold periodic Class Assemblies, to raise the problems of each class and collective forwarding of actions to solve them, as well as the consequences for those who do not follow the agreements, as cited by Araújo (2004), a space of constant elaboration and reworking of the rules of school coexistence, and therefore, a space for dialogue, negotiation and forwarding of solutions to resolve conflicts. Also according to Araújo (2004), such goals are achieved when assemblies are made official in the school with frequency and spaces determined for this purpose, and the project seeks to contribute to this movement when it proposes that the class assemblies are provided for in its PPP, ensuring them as another space for student participation, where he or she can have an active voice to address issues of school space more particular to him or her: the classroom. This articulation with the school's PPP "should provide multiple learning opportunities", providing the student with "a comprehensive and quality education" (Bernardo, 2020, p.91, in Yamazato \& Nascente, 2020). The project refers to the classroom, within its context, as a room-state, referring to the states that form a nation.

Anísio Teixeira, strongly influenced by John Dewey, believed that "the school would have a moral and social nature, and could function as a "kind of 'miniature community' participating in the permanent recreation of society", where "life itself would be present within it, and not only the socalled preparation for life" (Cavaliere, 2009, p.60, in Yamazato \& Nascente, 2020). The contextualization of the project takes place to the extent that the student, learning to mobilize collectively to solve problems in his classroom, will be able to reproduce these actions in his neighborhood, his city, his country, understanding citizenship from the micro to the macro: participating in the construction of the rights and duties of his state-room, learning how to inspect and guarantee them and, by sharing the solution to his conflicts, learning to solve them with collective actions, using peaceful methods, with dialogue and empathy, in an autonomous way, capabilities without which, a real democracy cannot be built. The development of socioemotional competencies in the PV curriculum component has much to contribute to these processes, since while the student encounters them, he develops them in his daily practice.

When we talk about citizenship and democracy, it is also necessary to think about politics, through which it is possible to build them. These three words are related in their practical meanings, they build on each other, reinforcing each other. And the school has its role to guarantee that the student will experience them, preparing him/her for life in society, which will demand from him/her 
competencies and skills so that he/she can really exercise them, becoming a competent citizen. For Araújo (2004), school democracy is based on education for citizenship, which is expressed by a set of rights and duties that allow the citizen the right to participate in political processes, including the right to vote, to participate in the making of laws, and to exercise public functions. Still according to Araújo (2004), this formation for citizenship, in order to configure and allow the effective participation of the citizen in the political and public life of society, must aim at the development of the necessary skills to deal with its processes, loaded with diversity and conflict of ideas, and the school must provide spaces for the development of the human being in this sense: physical, psychological, cognitive, ideological, and cultural conditions that are indispensable to achieve a healthy life, promoting an ethical, political, and psychological formation for all. Yamazato and Nascente (2020) conclude exactly that, that "it has become important to realize how integral education, as a schooling project, can contribute to a historical and planetary human formation, in the perspective of social justice and democracy. The proposal to hold class assemblies, as a model of participatory democracy, is of significant importance in the construction of school and social democracy, as a space for participation and exercise of protagonism, development of moral and ethical values, the understanding that, by finding, in a collective way, strategies to deal with the resolution of conflicts, provides a change in interpersonal relationships that, if properly coordinated with regard to mutual respect, help to build the democratic and dialogic school environment that is proposed (Araújo, 2004).

To form competent and autonomous students are the objectives of the pedagogical model of the Comprehensive Education Program, in addition to seeking to form them in solidarity. The Program elects four educational principles to guide, in a fundamental way, the constitution of its methodologies (São Paulo, 2012), and the Project My School is My Nation aims to support all of them:

- It considers Interdimensional Education when, as Costa (2007) says, it favors the dimension of corporeality (eros) and sentimentality (pathos), instead of only rationality (logos), through participatory practical actions that help changing management and teaching methods, because it is an education for values: caring for oneself (self-care), caring for the other (alter-care), caring for the environment in which one lives (ecocare), and caring for the meanings, senses, and values that govern one's existence (transcare);

- It considers the Pedagogy of Presence when it proposes to carry out actions where the presence of each one is valued, is a basic need, which collaborates with the development of selfconcept, self-confidence, and self-esteem. And there is nothing better than to do this in a shared way, understanding that one's rights and duties collide with the rights and duties of others, understanding what is meant by one's own and collective dignity;

- It considers the four Pillars of Education for the 21st century when it proposes a working method that necessarily implies the student's protagonism, their participation in assemblies and in conflict resolution, when, together, they will be developing their abilities and competencies to learn to know, to do, to live together, and to be;

- It considers Youth Protagonism in all its moments and actions, when it promotes the creation of spaces and conditions that give the student the possibility to engage in activities related to solving real, everyday problems (São Paulo, 2019).

Political education is intrinsic to the Project as an instrument of autonomy and emancipation, as considered by Hamze [200-?], leading the student to understand society and its forms of action, as an author who constructs and reconstructs his reality, developing the common good, social equality, and collective dignity, principles of citizenship and democracy. Hamze [200-?] also mentions that the school should support in its educational project the will to work on the ideals of citizenship, which is a fundamental component of democracy. The PCNs (Brazil, 1997) bring in their Principles and Foundations, that the school should provide experiences of different forms of socio- 
political and cultural insertion and should assume itself as a social space that provides the construction of the necessary ethical meanings that constitute all and any citizenship action. In its objectives for Elementary School, it also states that, at the end of this stage, students should be able to, among other things understand citizenship as a form of political and social participation; reproduce, in their daily lives, solidary and cooperative acts, rejecting injustice, demanding respect for themselves and respecting others; have the competence to position themselves in a critical, responsible and constructive way in their various social situations, in order to be able to use dialogue as a way to mediate conflicts and make collective decisions; perceive himself as a transforming agent of his reality; develop knowledge about himself, feeling confident in his cognitive, affective, physical, ethical, personal inter-relationship, and social insertion capabilities, seeking to persevere in the search for knowledge and in the exercise of citizenship (Brazil, 1997). In other words, everything that will be of extreme importance to him/her for adult life in society, and as a tool to fight for the maintenance of a democratic society.

This project emerges, then, as another possibility to solve the requirements of effective democratic management in school - making room for class assemblies and participation in conflict resolution - providing another opportunity for students to develop their protagonism and exercise democracy, collaborating with their full development and contextualization of their learning. This is because "to educate integrally goes through several dimensions of the subject's formation (cognitive, affective, cultural, social, ethical, political)" (Lobato \& Carvalho, 2014, p.870). And that this proposal of integral formation of the student "should be able to understand the school in its public dimension, as a forum of different voices and discourses" (Coelho, 2009, p.37 in Lobato, 2014). It is expected that the fact that the student actively participates in an assembly, has an active voice, learns to listen to the other, knows how to negotiate, reach a common consensus, elaborates the 'basic rule' of his classroom in a collective way, helps to supervise it together with his classmates, and learns how to solve conflicts within a Culture of Peace (Unesco, 1999), is an important contribution of the project to increase the sense of belonging of the student in relation to school, seeking to improve relationships and school environments. Also, perhaps, to imprint on the school an identity that characterizes it, as if it were 'its soul', an important and expected characteristic for a PEI school, as a democratic and participatory school. The introduction of the student-monitors of the day, within the project, came from a student's questioning, during a class on citizenship, in the subject of PV, if there were useless laws. In conversation with the class, the conclusion was reached that a law can become useless when it is created and not enforced.

As far as shared conflict resolution is concerned, observing, and taking as a guideline what the Manifesto 2000 (Unesco, 1999) says, the project brings its collaboration by covering the 6 points on which this document is based: respect life and reject violence, be generous and know how to listen to understand, preserve the planet, and rediscover solidarity. One of the phrases that inspired the birth of this project, and that came up within a Life Project class, is the phrase "What worries me is not the cry of the wicked, but the silence of the good", attributed to Martin Luther King. This phrase brought the inspiration of a union for the common good, from the observation that most students within the school in question, want their good, want a peaceful environment to study and live together. And, therefore, if these students unite, it is possible, in a peaceful way, to dialogue and try to make others aware that it is possible to establish a supportive environment, of cooperation, so that a quality learning environment, in all senses, can be established. In this sense, Abramovay (2003) reminds us that a quality education is one that is committed to the formation of minds focused on building a culture of peace, and that this can be built as early as possible. And in relation to this culture, the project is also strengthened in Abramovay's (2003) speech, when he says that it should be built through strategies, replacing conflict with dialogue, based on tolerance and solidarity, respecting all individual rights and citizenship rights. Frick et al. (2019) brings as an action related especially to conflict resolution: "it relates to the learning of conflict resolution by students, 
assertively and by the way teachers mediate or resolve them." To this end, they cite promoting actions that help students learn to resolve conflicts peacefully or assertively, the development of school assemblies, and training students to be student mediators of conflict. The moment classrooms started hearing about the project, about unity for the common good, and ways to unite to solve problems peacefully, it was automatic, for example, the initiative to start acting even before the project was implemented: during the class that quotes Luther King's phrase, an example was given of a line with ten people, where one of them cut in line because a classmate let him. The fact that the other eight people remained silent at this time was justified, in the students' voices, by the fear of an aggressive reaction on the part of the one who cut in/allowed to cut the line, or simply let them pass because of the intention of keeping away from conflicts, or because of shyness/not being able to have an attitude at that moment. They were then presented with a simple way to try to solve this problem, an action question: if this happened in the snack line, for example, wouldn't it be possible that the eight in their correct places in the line would just raise their arms simultaneously, indicating that something was not right there? This is what started to happen, automatically, the day after these classes in the classrooms: they began to spontaneously raise their arms when someone tried to break the line. In other words, the student longs to be a part of, to participate in, to be present at school moments, whatever they may be. Again, actions directly linked to the development of social and emotional competencies.

As for the feeling of belonging, Abramovay (2003) indicates that by allowing the participation of all its members in the various school activities, this feeling will be developed and will be directly related to the improvement of the school climate. This is the intention of the project: to make the student participate actively, during class assemblies, in the supervision of the agreements, in their moments of conflict resolution and in the monitoring and updating of the quality index of their classroom, which will be visible to all, on a panel placed in the schoolyard. Therefore, the project seeks, in addition to the co-responsible care of each classroom, the co-responsibility of the general care for the nation to which all classrooms belong, since the students should always be attentive, not only to the demands of their classroom, but also to the demands of the collective living spaces: there is no point in one or another classroom having good quality indexes if, in general, the nation is not doing well. And this context is of great importance, since it contributes to the students' understanding that although they are, in the first instance, part of a state-classroom, they are part of something bigger, which is their nation.

\section{Importance of school unit staff}

The elaboration and implementation of a project that intends to contribute to democratic processes within a school unit is always a challenge, however congruent the profile of its manager may be. A manager alone cannot truly and truly transform a school into a real space for democracy without ensuring that this participation is for all and with all, seeking the involvement of the whole school unit team, understood here as managers and other employees, who must always be in tune in their actions and united in their objectives.

For the project to achieve positive results, it is necessary that the team works together, each one with his or her own role, but keeping the collective purposes focused on a common goal, within a culture of peace, and as Abramovay (2003) indicates, in schools, it is recommended that the whole school team be involved in this process: managers, teachers, students and employees. "The construction of a democratic, innovative climate that promotes the transformation of what we have today goes through the understanding that basic education institutions need to be in tune with their times, allowing the renewal of the imaginary potential and utopias of its members, to enable the structural change of the processes experienced in the educational and social environments. It is necessary to think and promote an integration between the contemporary time with the 
pedagogical proposals, with the different knowledge and actions experienced by the school community (Amorim, Matta, \& Freitas, 2017). Within an IEP, this collective commitment should already exist, since it is part of the premises of the program, such as Protagonism, with its macro indicators Respect for Individuality, Promotion of Youth Protagonism, and Senior Protagonism (where the document makes it clear that the professional should act serving as an example educational presence); Co-responsibility, with its macro indicators Relationship and Collaboration and Coresponsibility, and Excellence in Management, with its competency Commitment to the process and result, especially with regard to contributing to the achievement of the goals of the School Action Plan (São Paulo, 2015).

As Lück (2010) suggests, to the extent that school practices are guided by consistent philosophy, values, ideas, and principles, determined by what goes on in people's minds and hearts, and that determine their ways of being and doing, democratic management occurs. Therefore, it is necessary that the school manager knows that the power of decision is not in his hands, but in the school collective, which allows autonomy and shared decisions. The involvement of all members of the school team is extremely important for the positive outcome of the project, because without the collaboration of all, without understanding this new methodology, with more active participation of students, and that stirs even more their movement within the school, this would be impossible. And not only the school staff, but what is desired is "to undertake collective movements of methodological innovation regarding what and how occurs the organizational, intellectual, and affective daily life inside the school, aiming at a greater dynamic: the construction of paths and cultural, social, and educational possibilities that promote the very transformation of the school in all aspects, including social, relational, pedagogical and managerial. (Amorim, Matta, \& Freitas, 2017). In the example given above, about the peaceful attitude to be taken, when witnessing someone cutting the lunch line, for example, it is essential that the presence of a teacher, or manager, or school employee, is made attentive to all that movement, just to ensure that the act of raising hands, in silence, to correct an unfair act, is recognized and validated, bringing to the protagonists of the action, a positive reinforcement that they can help change the climate and school relations, safely and without conflict.

It is necessary that the entire school staff understand the project's actions and ensure that the students feel safe and confident to get involved in its processes and practical actions. The school already has a team that is united and committed to the educational processes, which will facilitate this whole process. "It is the role of managers, teachers, students, and family to act in an integrated and receptive manner to new forms of possibilities for building more opportunities, for the realization of a learning process that is egalitarian, integrative, open, attentive to political issues, contemporary knowledge and information" (Amorim, Matta, \& Freitas, 2017, p.1816).

In relation to the manager, by allowing and committing to the realization of this project in school, reaffirms his efforts to increasingly transform the school into a democratic space, agreeing with what Lück (2010) points out, who says that for the effectiveness of a democratic management, there must be expansion of decision spaces that enable the exercise of autonomy, with the adoption of interactive, participatory and democratic practices, which have as a characteristic the search for overcoming, collectively, the problems faced. Yamazato and Nascente (2020), cite Paulo Freire and his understanding that the appropriation of scientific, technological, and cultural knowledge, offered by full-time school education, provides a human formation for autonomy and democratic participation aimed at the exercise of citizenship. Still in this sense,

Freire is used because the field of didactics needs practices based on autonomous and creative social interventions, based on what freedom and autonomy can constitute. Freire's work allows us to state that there is a guideline that makes it possible to ground epistemology, politics, and pedagogy, which makes it necessary to return to his conceptions as a fundamental axis for reflection on the historical project. Freire because it helps to sustain that the project of 
organizing the relations that take place in the school, because human relations, now in progress, must be radically questioned by its practices and its concepts, put in a climate of constant tension (Ghiggi, Chaves, \& Pereira, 2019, p.50).

Regarding the other members of the school team, they must also be open to this paradigm shift that involves the implementation of democratic management, and that also appears in the PEI premise Replicability, in the competence Solution and Creativity and, more specifically, in its macro indicator Creativity, where the document points to the willingness to change and flexibility to adopt new practices (São Paulo, 2015).

The implementation of this project focuses on valuing students, paying attention to their demands, and contextualizing their learning for the exercise of citizenship and democratic processes within the school, respecting and valuing the Guidelines of the Comprehensive Education Program (São Paulo, 2012), with the BNCC (Brazil, 2017) as a backdrop, as well as other documents that permeate and ground each of its actions.

A school that learns and, therefore, is open to the democratic process, according to Senge (2005), is one that uses methodologies that increase the quality of thought and forms of interaction, changing the way people interact and that, as part of an individual purpose, makes sure that everyone succeeds.

Given the results found in this study, it is possible that the project will be successful in this school unit, as it is already inserted in several participatory actions, inside and outside the school, being a school that has all the characteristics for this project to work: an administration open to democracy, a school team united and willing to collaborate, and students who are already inserted in several other forms of democratic participation. It is also an important action to prepare students for their new stage: High School. Falcão and Silva (2020) rightly discuss the high school student's ability to participate in democratic processes within the school, and that the protagonism may still be something to be conquered by them. If there were this development at the end of Elementary School II, the student would already be more familiar with the processes of democratic participation in High School.

\section{CONCLUSION}

This study sought to make a literature and document review of books, articles, and internal documents of the school, to substantiate and support the implementation of the Project My School is My Nation within the school unit. The project's principle is to institute class assemblies as a strategy to increase the student's sense of belonging and to improve the school climate, and both the literature studied and the school documents corroborate its viability, considering that it contributes to the opening of another space for democratic participation in the school, helping to build its effective democratic management and providing the students' protagonism and autonomy. Elementary School II is the moment of entry into adolescence, an important moment of identity and values consolidation, a period of adaptations to the process of beginning to understand how to deal with the responsibilities they will have as adults. The democratic processes are important for the student, within an integral education, to understand his citizenship as the exercise of his rights and duties, a space to speak and listen, and the exercise of protagonism. Research conducted with high school students in Amazonas, "show that young people resent listening spaces, even in institutions socially referenced as places for young people, such as school.", and it would be very good if the students already leave Elementary II, having known and participated in democratic processes, and therefore, of listening. (Falcão \& Silva, 2020) Thus, and within this context, the project has all the elements to promote the continuity of the actions that are already underway in the school, constituting itself in an integral way, from the insertion of the guarantee of assemblies in its PPP contributing to its construction and continuous review, as well as in its movement towards enabling 
the school to acquire its own characteristic, or the identity it seeks so much, imprinting it with a soul that can characterize it and give it reference.

The understanding here, of how the school should be conceived, compacts with what Sousa, Przylepa and Assis (2019, p. 2346) suggest, when they say that "the school should be conceived and transformed into a locus that privileges the struggles, the contestations of social differences and is concerned with the human formation of the individual, regardless of their origin or social class. It must build mechanisms that encourage social participation, democracy, citizenship, inclusion, and create bonds of solidarity and fraternity. The school curriculum needs to educate beyond skills and abilities. The student needs political and critical education, which will enable him to apprehend and understand the reality he experiences, and, in this way, he will have concrete conditions to interfere in his social reality". The intention to imprint a soul in the school is also contemplated in this reasoning when it is observed that the school must have a PPP that makes clear what is its vision regarding the citizen, society, and education that it wants to be supported by all, because this should also express the school identity (Sousa, Przylepa \& Assis, 2019). The My School is My Nation Project brings the possibility of, in practice, transforming the school environment, with all its events, into a laboratory of citizen experiences, figuratively as residents, belonging each, to their "room-state", and collectively, to their Nation, which is the school. A laboratory inserted in the real school life, where the student will be able to learn, in a playful and participatory way, how important it is, for life outside school, the exercise of citizenship, of democracy, of having one's rights assured, while one must fulfill one's duties. A project that teaches citizenship, solidarity, politics, protagonism, democracy, where the citizens of the school Nation live together to ensure what is best for the group, helping to build not only a better learning and living environment at school, but also the understanding of the importance of these concepts and processes in adult life, in living together in society, and in ensuring equal rights for all. Learning citizenship at school, for life: belonging as a form of citizen action, from the classroom to our country.

Authors' Contributions: Lacerda, R. P.: conception and design, acquisition of data, analysis and interpretation of data, drafting the article, critical review of important intellectual content; Marques, R. N.: conception and design, acquisition of data, analysis and interpretation of data, drafting the article, critical review of important intellectual content. All authors have read and approved the final version of the manuscript.

Ethics Approval: Not applicable.

Acknowledgments: Thanks to the Institute of Research and Continuing Education Economics and Business Management, Pecege, and Professor Pedro Valentim Marques for the incentive and the scholarship granted. To Christina Negro Silva, director of E.E. Dr. Prudente - PEI for the support. Work awarded as the best monograph defended in the MBA course in School Management USP/ESALQ, in the XIV SIM, held in July/2020.

\section{REFERENCES}

Abramovay, M. (2003). Violências nas escolas. Unesco, Brasília, DF, Brasil.

Amorim, A., Matta, A. E., \& Freitas, K. S. (2017). O retrato holográfico do gestor da escola básica e a necessidade de novas possibilidades gestoras. Revista Ibero-Americana de Estudos em Educação, 12(3): p. 1802-1819.

Araújo, U. F. (2004). Assembleia escolar: um caminho para a resolução de conflitos. São Paulo, SP: Moderna.

Artexperiência. (2019). Retrieved from www.artexperiencia.com.br

Bogdan, R., \&Biklen, S. (1994). Investigação qualitativa em educação: uma introdução à teoria e aos métodos. Porto: Porto Editora.

Bordenave, J. E. D. (1994). O que é participação (8a ed). São Paulo, SP: Brasiliense.

Bourdieu, P. (2007). A distinção: crítica social do julgamento. Porto Alegre, RS: EDUSP.

Brasil. (1988). Constituição da República Federativa do Brasil de 1988 (35a ed). São Paulo, SP: Saraiva. 
Brasil. (1996). Lei no 9.394, de 20 de dezembro de 1996. Estabelece as diretrizes e bases da educação nacional. Diário Oficial da República Federativa do Brasil. Retrieved from http://www.planalto.gov.br/ccivil 03/leis/19394.htm

Brasil. (1997). Parâmetros curriculares nacionais: introdução aos parâmetros curriculares nacionais. Retrieved from http://portal.mec.gov.br/seb/arquivos/pdf/livro01.pdf

Brasil. (2014). Lei n. 13005, de 25 de junho de 2014. Aprova o Plano Nacional de Educação. Retrieved from http://pne.mec.gov.br/18-planos-subnacionais-de-educacao/543-plano-nacional-de-educacao-lei-n-13-005-2014

Brasil. (2017). Base Nacional Comum Curricular. Brasília, DF: MEC.

Costa, A. C. G. (2007). Você é mestre quando aprende. Retrieved from http://revistapontocom.org.br/2007/10 Delors, J. (2003). Educação: um tesouro a descobrir (8a ed). São Paulo, SP: Cortez.

MuroArte. De mão em mão, muro de escola em Piracicaba se transforma e vira mural de arte. Portal do Governo. Secretaria da Educação, 2019. Retrieved from https://www.educacao.sp.gov.br/noticia/boas-praticas/de-mao-emmao-muro-de-escola-em-piracicaba-se-transforma-e-vira-mural-de-arte/

Falcão, N. M., \& Silva, S. S. (2020). Student's participation in upper secondary school management: approaches to the reality of the school system in the state of Amazonas. Revista Tempos E Espaços Em Educação, 13(32): 1-19.

Fernandes, F. (2017). Projeto fortalece sentimento de pertencimento dos alunos à E.M. Bernardo de Vasconcellos. MultiRio. Retrieved from http://www.multirio.rj.gov.br/index.php/leia/reportagens-artigos/reportagens/13383projeto-fortalece-sentimento-de-pertencimento-dos-alunos-\%C3\%A0-e-m-bernardo-de-vasconcellos

Frick, L. T., Menin, M. S. D. S., Tognetta, L. R. P., \& Del Barrio, C. (2019). Estratégias antibullying para o ambiente escolar. Revista Ibero-Americana de Estudos em Educação, 14(3): 1152-1181.

Ghiggi, G., Chaves, P. M., \& Pereira, D. A. (2019). Do formalismo didático à experiência da consciência: Paulo freire e a substantividade democrática na escola pública-popular. Revista Ibero-Americana de Estudos em Educação, 14(1): 4662.

Hamze, A. (200-?). Política, cidadania e democracia. Artigos, Brasil Escola. Retrieved from https://educador.brasilescola.uol.com.br/gestao-educacional/politica-cidadania-democracia.htm

Lisboa, Z., Jamar, G., Santos, T., \& Lopes, P. (2014). Construindo identidades. Universidade Federal dos Vales do Jequitinhonha e Mucuri. Retrieved from http://site.ufvjm.edu.br/pibidlereser/files/2014/12/CONSTRUINDOIDENTIDADES.pdf

Lobato, I. M., \& Carvalho, D. V. (2014). Família e escola de tempo integral: um diálogo necessário na formação do sujeito. Revista Ibero-Americana de Estudos em Educação, 8(4): 681-874.

Lück, H. (2010). Concepções e processos democráticos de gestão educacional (6a ed). Petrópolis, RJ: Vozes.

Oliveira, I. B. (2009). Democracia no cotidiano da escola. Petrópolis, RJ: DP et Alli.

Organização das Nações Unidas para a Educação, a Ciência e a Cultura [UNESCO]. (1999). Manifesto em defesa da paz. Retrieved from http://www.direitoshumanos.usp.br/index.php/UNESCO-Organiza\%C3\%A7\%C3\%A3o-dasNa\%C3\%A7\%C3\%B5es-Unidas-para-a-Educa\%C3\%A7\%C3\%A3o-Ci\%C3\%AAncia-e-Cultura/manifesto-em-defesa-dapaz-2000.html

Pena, R. F. A. (200-?). "O que é nação?". Brasil Escola. Retrieved from https://brasilescola.uol.com.br/o-quee/geografia/o-que-e-nacao.htm

São Paulo. (2012). Diretrizes do Programa Ensino Integral. Retrieved from https://www.educacao.sp.gov.br/a2sitebox/arquivos/documentos/342.pdf

São Paulo. (2014). Resolução SE-68, de 17 de dezembro de 2014. Dispõe sobre o processo de avaliação dos profissionais que integram as equipes escolares das escolas estaduais do Programa Ensino Integral. Retrieved from http://siau.edunet.sp.gov.br/ItemLise/arquivos/68 15.HTM?Time=18/04/2018\%2017

São Paulo. (2015). Mapa de Competências: Programa Ensino Integral. Retrieved from https://pt.slideshare.net/RoseliBasellotto/mapa-de-competncias-ensino-integral-1-1

São Paulo. (2020). Currículo Paulista. Retrieved from https://efape.educacao.sp.gov.br/curriculopaulista/

Schimonek, E. M. P., \& Adrião, T. (2018). A gestão dos Programas Mais Educação e Escola a Tempo Inteiro: uma análise de políticas para educação em tempo integral [Ed. Especial]. Revista on line de Política e Gestão Educacional, 22(1): 223-243. 
Senge, P. (2005). Escolas que aprendem: um guia da quinta disciplina para educadores, pais e todos que se interessam pela educação. Porto Alegre, RS: Artmed.

Sousa, A. P. M., Przylepa, M., \& Assis, R. M. (2019). Elaboração, atualização e a participação da educação física no projeto político pedagógico escolar. Revista Ibero-Americana de Estudos em Educação, 14(4): 2345-2357.

Suassuna, L. (2008). Pesquisa qualitativa em educação e linguagem: histórico e validação do paradigma indiciário. Retrieved from https://periodicos.ufsc.br/index.php/perspectiva/\%20article/viewFile/10310/9576

Valle, L. (2016). Exemplo de gestão democrática, escola municipal de SP realiza assembleias com alunos. Instituto Claro. Retrieved from https://www.institutoclaro.org.br/educacao/nossas-novidades/reportagens/exemplo-degestao-democratica-escola-municipal-de-sp-realiza-assembleias-com-alunos/

Yamazato, M. O., \& Nascente, R. M. M. (2020). Concepções, projetos e experiências de educação integral no Brasil. Revista Tempos Espaços Em Educação, 13(32): 1-20.

ZHANNAT, S.; KUATOVNA, A. S.; ASAUOVNA, Z. A.; RAHMETZHANOVNA, B. G.; ZINA, A.; D DARAZHA, I.; SAIRA, Z.; SALAMATOVNA, A. D. (2021). Características da organização do trabalho nas principais fases do projeto nas aulas primárias [Ed. Especial]. Revista on line de Política e Gestão Educacional, 25(2): 828-841.

Received: 7 June 2021 | Accepted: 31 August 2021 | Published: 25 September 2021

This is an Open Access article distributed under the terms of the Creative Commons Attribution License, which permits unrestricted use, distribution, and reproduction in any medium, provided the original work is properly cited. 